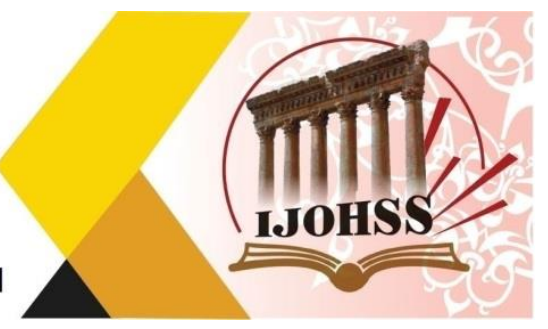

\title{
Evaluation of Women's Political Participation in Iraq before and after 2003 (A comparative study)
}

\author{
Ali Mohammed Hasan \\ College of Law \\ University of Al-Qadisiyah \\ Iraq \\ Email: ali.mohammad@qu.edu.iq
}

\author{
Omar Saad Khalid \\ Law Department \\ Al-Mansour University College \\ Iraq \\ Email: omer.khalid@muc.edu.iq
}

\begin{abstract}
Iraqi women suffer from the political domination of man who seeks to undermine and curtail women's roles, especially in relation to decisions and issues crucial to a number of laws that require acceptance or rejection. There are significant challenges have that faced women as an obstacle to their participation in political life alongside men. The most important challenge is the Arab social heritage which restricts women to seize the available opportunity to get the position of a sovereign post or as a decision-maker. Although the Iraqi Constitution guarantees the participation of women in the political process, such participation remained limited. On this basis, the role of Iraqi women in political participation is very limited and it is associated mainly with heads of blocs and not the member himself, whether man or woman. Despite the limited participation of Iraqi women, especially in political fields (parliament, ministries and institutions), but their roles are still evident in the army, police and judiciary fields, even they outnumber men sometimes. Nevertheless, the Iraqi women differ from women in women in Middle East because they are living in a country that had been suffered many wars and calamities. However, they are still performing their role naturally, thus the decision-makers in the Iraqi government must take into account this segment, which is half of the society.
\end{abstract}

Keywords: Evaluation of Women, Political Participation, Iraq. 


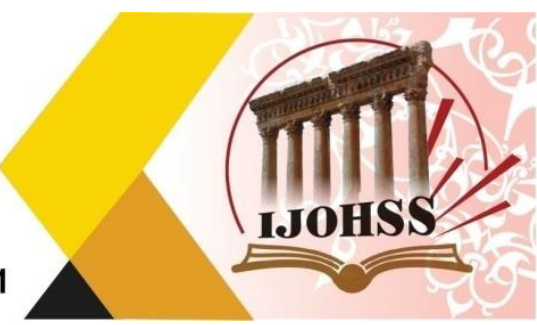

\section{Introduction}

The Iraqi women have given sacrifices in all fields of life; they have suffered from various kinds of persecution and violence because they are the weakest element in society and they lack sufficient protection. Women in Iraq are the first victims of human rights violations, in families, the streets, the government institutions, or amongst extremist groups of various orientations. However, Iraqi women have shown the genuine face of women worldwide suffering from a lot of catastrophes and wars before and after 2003.The Iraqi women have participated in all political decisionmaking positions such as the government institutions, the army, police and other sites that require the presence of women on a permanent basis. Despite the threats and risks which have reached sometimes to rape, murder and kidnapping, the Iraqi women have continued in the political, economic and social approach to rebuild the new Iraq. On this basis, this paper attempts to clarify the genuine roles of the Iraqi women in political, legal and military fields before and after 2003. Shouldering responsibilities, Iraqi women have been faced many challenges and obstacles that have caused them a lot of problems. In the forefront of these problems were the men controlling the important decision-making posts whether in governmental or non-governmental establishment.

In addition, the traditions and social norms have obstructed sometimes the aspirations of Iraqi women to practice their legitimate role. Also the absence of the political and legal guarantees in the Iraqi constitution to guarantee women's right to participate in the political decision-making positions in parliament and the Iraqi government has rendered this participation weak.

The research has essayed to prove hypothesis that is the participations of Iraqi women in all fields and actions have been indicated that they are immoderately still suffering from undermining by men and other obstacles, which would generate to the sapping of their political, statutory and social participation. It is due to several reasons in relation to the personality of complicated Iraqi society as well as the nature of the prevalent political system alike before or after 2003.

However, research problematic has tested to answer the following questions:

1. How is the beginning of Iraqi women's political participation before 2003?

2. How is the beginning of Iraqi women's political participation after 2003 ?

3. What are major obstacles to women's political participation?

4. What are the most prominent fields which Iraqi women participated?

Consequently, research has divided into main four six, as follows:

1. The beginnings of women's political action (before 2003).

2. The role of women after 2003 (post-Baathist Iraq).

3. Barriers to women's political participation.

4. The categories of Iraqi women who have worked in the political sphere.

5. The participation of women in the judiciary.

6. The role of women in army and police. 


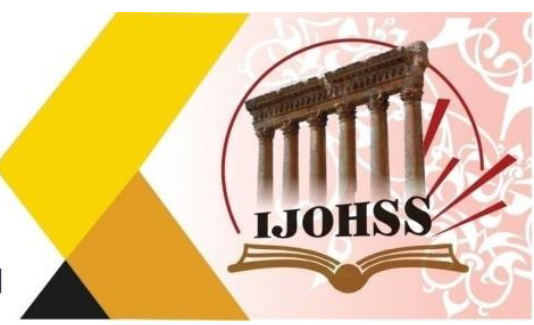

Section I: The beginnings of women's political action (before 2003)

The role of Iraqi women in the public life began in the early twenties of the last century. The involvement of women in that period was a result of the high proportion of women's education in Iraq in the late thirties, where women resorted to enter into fields of study in different schools and universities which were limited to males only in the past, for example women joined in the field of law and medicine. As a result of progressive and liberal attitudes that prevailed in the forties, Iraqi women participated in partisan political work and various political events. For example, women participated in the uprisings especially the so-called the bridge uprising, in which Iraqi women gave one martyr in 1948, whom known as the martyr of bridge. In 1952 the first woman was appointed as minister for municipalities who was Dr. Naziha Dulaimi ${ }^{1}$.

On the other hand, Iraq's interim constitution of 1970 ensured the equal opportunities for all citizens regardless of sex, but it did not mention any mechanisms that can help to guarantee or ensure the political participation of women. However, women were present in the Iraqi National Council during the period 1980-1995, when nine member women were by 1990; the participation rate of women rose to reach $13.2 \%$ of the total membership. But at the fifth session of the National Council of Iraq in 2000, the number of women reached $20(8 \%)$; this is a perfect ratio compared to women's participation in the Arab region in that period ${ }^{2}$. As for the participation in the political parties that were active at the time the membership was limited. The female party members did not increase in the ruling party about 5.4\%; it was Dr. Huda Salih Mahdi Ammash was elected as member of the national leadership of the Baath Party ${ }^{3}$.

Noteworthy, Iraqi women did not get ministerial positions although much the Iraqi state institutions have been run efficiently by women due to the emergence of an Iraqi Women's competencies and the preoccupation of men in the repeated military actions. Hence, the question why did not Iraqi women demand to participate in political decision-making positions, especially when they were efficient, effective, and qualified to achieve political participation? Has to be asked. It is possible that this case is the result of the following reasons ${ }^{4}$ :

1. The nature of the difficulties faced by women in Iraq and the multiplicity of fronts struggle helped to find some kind of interim satisfaction in prioritization. The political situations have affected negatively the demands of women in Iraq; women faced the security, political, economic, and social burdens, in addition to educational and psychological ones ${ }^{5}$. It was difficult to speak about women's claims to participation in decision-making positions before getting the essentials and basics of life.

2. The nature of the prevailing regime in Iraq in that period rejected any criticism for its ideas.

3. The lack of women's organizations in Iraq which could demand women's rights except the General Federation of Iraqi Women which was financed by the Iraqi government and was part of the leans to government's establishments at that time. 


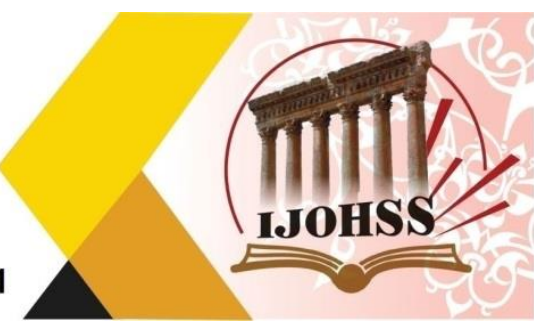

The women had a big role to participate in the political parties which opposed the Baath party at the time such as Islamic Dawa Party the Democratic Party of Kurdistan. Therefore, some women were exposed to many kinds of torture, arrest and prison and others managed to escape out of Iraq (Iran, England, the United States, the Netherlands, Denmark and Australia). However, women's portions were limited by liberal or Islamist parties. Women participated in the struggle of the Kurdish parties against dictatorship; this helps effectively the military action within the so-called the Peshmerga forces.

Women left their husbands and children and joined the military training on the mountains of Kurdistan ${ }^{6}$. The most effective participation in decision-making for women in the province of Kurdistan was the period of 1992_2004 when the percentage of women's representation in the National Council of Iraqi Kurdistan was 7\%. Women also participated in the Kurdistan regional government ${ }^{7}$. Dr. Kafia Suleiman was the first woman minister of the municipalities ministry in 1996. In addition, many women were appointed as deputies to minister, mayors, directors and judges. Today there are 29 women members out of 111 in the Parliament of Kurdistan and three women ministers in the government which consists of 40 Ministries ${ }^{8}$.

\section{Section II: The role of women after 2003 (post-Baathist Iraq)}

Despite the democratic changes in Iraq, Iraqi women tried hard, without real success, to get their just right. The main players of the change process announced that the major objective is to spread democracy on the grounds that most of them had left Iraq due to the absence of democracy and returned to rebuild it in Iraq ${ }^{9}$. Indeed, it was strange that female representation in the first political block after changing Saddam's regime was very meager. Only three women out of 25 members in the Iraqi Interim Governing Council were appointed in 2004. Women's share of ministries was only 4: the ministries of Labor and Social Affairs, Municipalities, Agriculture and the State ministry for Women's Affairs ${ }^{10}$.

Article $\mathrm{C}$ of the State Administration Law for the transitional period provided that the election law aims to achieve a percentage of women's representation no less than one-quarter of the members of the National Assembly. Then the Article 3 of Order No. 96 Section 4 of election law issued by the Coalition Provisional Authority to name at least the first three women of candidates on list; two women should be chosen out of the first six candidates in the list, and so forth until the end of the list. As a result of the application of this system the number of women reached 87 women out of 275 members in January $2005^{11}$. Women got six ministerial positions out of 36 ministries in the transitional government. Also women did not hold office of any the four sovereign positions. Therefore, the female representation of $11 \%$ in the Cabinet and $32 \%$ in the National Assembly. This indicates tacitly that there is no legal text in the administration law of state that would specify a minimum of women's representation in the executive or judicial positions ${ }^{12}$.

The provincial elections in Iraq was conducted in 2005 and it observed the proportional representation applied by the Transitional National Assembly. However, this mechanism of the proportional representation resulted into fewer women than the 


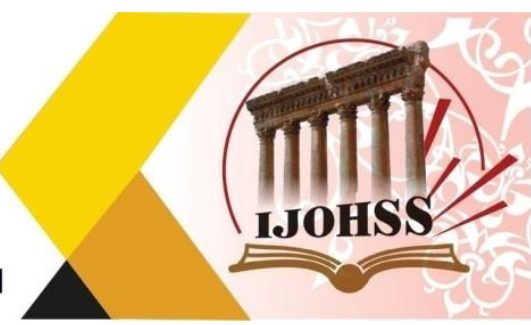

prescribed percentage. For example, the Council of Salahuddin province, there were 10 women out of 41 members and that means 24\%. The Council of Maysan province had the same numbers, in the Council of Dhi Qar province there were 9 women out of 41 members (22\%) and in Karbala Province there were 8 women out of 41 members $(19.5 \%)$. In addition, there were no female mayors or assistant mayors ${ }^{13}$.

In the last election of the Council of the provinces the female representation in most of the Iraqi provinces has been achieved, which was $25 \%$. Thus when a committee to draft a constitution consisted of 55 members, they comprised 9 women numbers and this was encouraging ${ }^{14}$. The new Iraqi constitution indicates in more than one article to enhance the equality between males and females in political rights. Article 49, paragraph 4, refers to customize a constant percentage of female representation in the House of Representatives by at least $25 \%{ }^{15}$.

The issue of proportional representation of women caused a widespread controversy, especially in the stage of the writing the Iraqi Constitution. The first draft of the Constitution, which was leaked, real trends to ignore called the development of mechanisms guaranteeing the achievement of political participation under the pretext that the quota text opposed with the principle of equality enshrined in the same constitution .

On this basis, the feminist movement began a strong opposition to this approach across a wide pressure campaigns on members of the constitutional committee and political leaders who have a genuine impact on the political process. Indeed, Iraqi women succeeded in promoting their rights regarding the quota system. Hence, when the Council of Representatives of Iraq was elected were 74 women members $(25.8 \%)$. Also when the Committee on Constitutional amendments was formed, it included 2 women out of the 27 members $(7 \%)^{16}$.

However, women are denied the posts of Presidency in the legislature and also it missed Security and Defense ministries. Also and women's representation in the executive authority retreated after the 2010 elections. In addition, women did not get any ministerial portfolio except the post of Minister of State for Women's Affairs, which suffers from a lack of the sufficient funding allocations to promote its activities of women ${ }^{17}$.

In fact, the main reason for the weakness of women's work in the political participation is the quota which has been adopted on number of women rather than their efficiency.

The advancement of women depends on two issues: the first thing is the presence of women in the parliament (legislature) and the Council of Ministers (executive) in order to be able to participate in implementation and legislation simultaneously. The other thing is that they are not given post at the level of leadership because of their lack of experience in the parliamentary work. Yet this does not mean that all parliament women do not have roles; some of them, especially in regards to the role and experience of the previous parliamentary sessions, women had a real role in many of the laws and issues, as well as debates, votes and legislation. 


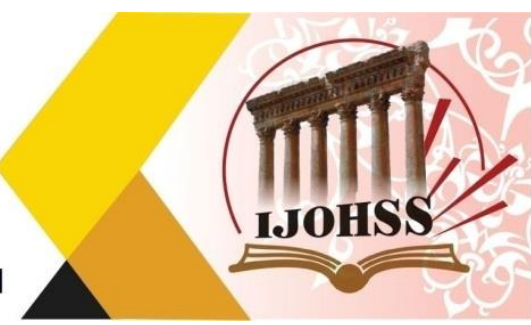

In the field Iraqi parliamentary women's achievements, they have achieved a number of important laws that are related to Iraqi women directly or indirectly, especially when they established the Parliamentary Committee of Women, Family and Children in $\operatorname{Iraq}^{18}$.

1. The law prohibits the import of games which instigate violence.

2. Refusal of the jaafari law which allow men to marry 9-year-old girls.

3. Approval to issue the law of social society in Iraq.

4. Accession to the Hague Convention, which is committed to protect children who are abducted and detained.

\section{Section III: Barriers to women's political participation}

Political participation is the entire volunteer activities carried out by individuals and participate through it with other members of the community, whether in the choice of the ruling elite, directly or indirectly, or to participate in decisionmaking or steering state's public policy. If democracy requires the participation of all members of the community in the political sphere, the application of democracy requires broader participation of women. But it remains just a theoretical matter that may not correspond completely with the distribution of power according to gender at the level of reality. There are many state constitutions have not distinguished between the rights of men and women in the field of political participation; at the same time they do not include guarantor to apply this. Besides there are some constitutions that have overlooked women's right to the political participation ${ }^{19}$.

The phenomenon of the limited political participation of women is the outcome of interacting and overlapping of community factors, whether political or economic, social or cultural or religious. Some are due to:

1. The constitutional and legal reasons, where legislature does not provide principle of equality between males and females with regard to some political rights. This may guarantee the right of nomination and election of women but those rights remain inoperative entirely or partially to the lack of a guarantor for the implementation of this as we have said ${ }^{20}$.

2. High illiteracy rates among women in the developing societies hinder their political participation significantly.

3. The emergence of terrorist movements that oppose women's rights, alongside the emergence of the forces of political Islam, which have deprived women of any political role. This point is the main handicap and barrier to women's participation in political field. Thus access to decision-making positions, which have exposed many political women activists of women to death threats and violations of their rights ${ }^{21}$.

4. The wide interest of the press and media in men contributes to the relative weakness of women. This will contribute to the reduction of the capacity of women to participate effectively in the public activities related to the society and the state ${ }^{22}$. 


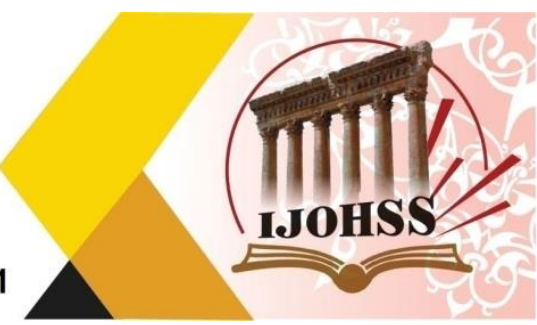

5. The men dominance on the overall political process; here jurisprudence in Iraq tends to adopt a two-way interpretation of male's control over the political process $^{23}$ :

- The nature of Iraqi society imposes on women to stay at home, especially for child-rearing.

- Traditions, customs and social norms control the political process in Iraq; there is a tradition in Iraq that man is more loyalty to the clan than woman. Of course, this leads to supremacy of men over women in elections.

In addition, there are fundamental reasons for the failure of Iraqi women in parliament. The heads of political blocs always try to prevent his political deputies to express their views or their participation in debates and decisions relating to sensitive political topics. The political permission and participations are limited to heads of blocs and parties or their representatives of men. Another factor that affected the failure of the political role of women within the Iraqi government is the domination of the three presidencies over all major decisions and these are monopolized by men. This was clear when a number of prominent women politician were excluded from the media spotlight because of their statements that are not beneficial to their political parties.

Despite the absence of women in power and decision-making positions, there is a public support demanding for the presence of women in decision-making positions. Consequently, in 2013 a study conducted a survey of Iraqi citizens, male and female, has showed that most respondents and by $(80 \%)$ they believe (strongly support) in the importance of women's political role, especially if they have a culture and consciousness far from sectarianism and the narrow mindedness. Those who did not believe (opposite) in the importance of the role of women in political life constitute a proportion $(20 \%)$ of the sample. They stated that women are not fit to be part of the political process because they are extremely emotional, which could affect their various decisions ${ }^{24}$ (See Figure 1). 


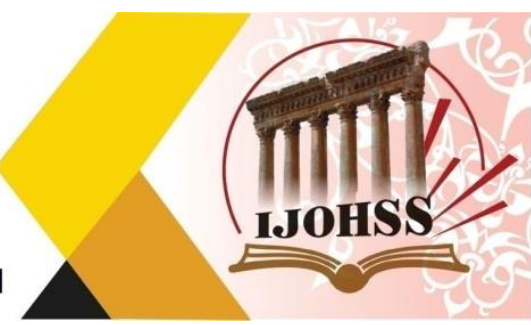

(Figure 1) Percentage of the sample shows supporters and opponents of the role of women in political life

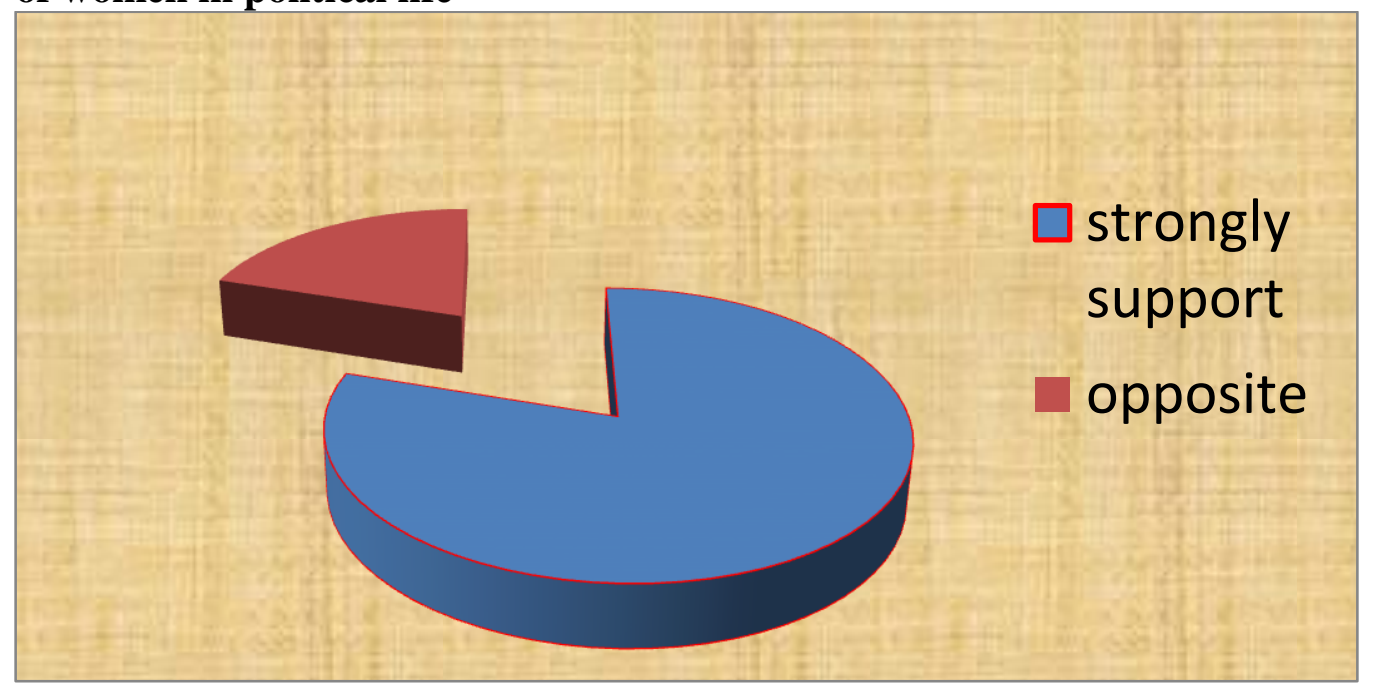

Section IV: The categories of Iraqi women who have worked in the political sphere.

The participation of Iraqi women in the political field is the issue of conflict between what Iraqi societies aspire to achieve in the shadow of the prevailing democracy and the reality of Iraqi society which is governed by clan, customs and traditions. The subject of women's rights and freedom is one of the sensitive topics because their presence is a measure of the culture of nations and peoples, thus detraction from these rights will reflect negatively on the entity of family and society on the grounds that women are half of the society ${ }^{25}$. However, the culture of women and their awareness play a real and important role in determining how to protect their rights as well as there is the true will to exercise these rights or freedoms.

The most important of these rights and freedoms is the right of Iraqi woman in the political participation. But what threatens women's political rights in Iraq is the government which is unable to implement its commitment toward women. For example, there is the Ministry of State for Women's Affairs, but it is just an office belonging to the Prime Minister's Office; it does not have a separate budget to cover their activities ${ }^{26}$. In addition, other factors hinder women in the political field such as illiteracy and the lack of programs of the political education.

Some political parties have tried to marginalize the role of women in an indirect way by selecting some women randomly and give them prominent political positions. Not only this, these women usually do not have political experience or certificates that qualify them for these positions ${ }^{27}$.

This adversely affects the role of women in the political process and society's perception of woman. What explains this is what happens in the local or provincial 


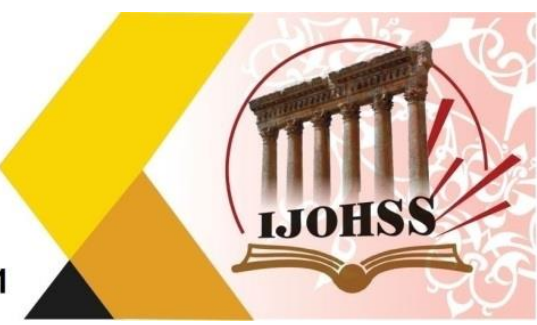

councils, parliament and ministries, where there is a little role allotted women to prove their ability in building a new Iraq.

In fact, the Iraqi women who have worked in the political sphere are divided into three categories. The first category wants to work hard in order to prove themselves and it usually involves more than one committee to win attention, but they do not have sufficient experience which qualifies them for that. As a result, they often fail due to lack of specialization and that the large number of tasks assigned to them are not satisfactory for their work in any committee is undoubtedly flawed, and this groups is not useful in the political work; this needs strategic planning and organization $^{28}$.

The second category, it has a limited experience which out of their participation some courses, but because of absent of women do not want to offer something to the community as a result of exposure to violence by the authorities. This has a negative impact on the political work; hence this group is more endangered than the previous groups.

The third group, the so-called spectator, thinks that the political work does not mean anything and it tries building a small Iraq (home) ignorant of a wider Iraq (home). This category is always anaclitic with the largest and smallest things; therefore this group usually enters into alliances with the strong groups for the personal interests ${ }^{29}$.

Arguably, the failure of women in the political field does not represent the true role of Iraqi women, but opportunities have given them positions. Also there are many women who deserve the positions and they want to work but they are not given proper chance to do things for one reason or another, and usually the main reason is the weakness of the political party which they belong to ${ }^{30}$.

In fact, the situation will remain as it is for what is so-called quota which means the $25 \%$ representation of women. This means the imposition of women on society without their will, here this will to lead to a kind of dictatorship of the electoral women. The best evidence of this is by the provincial elections in 2008 when women did not get enough votes compared to men. Therefore, to reach the prescribed percentage of $25 \%$ men lost some of their votes ${ }^{31}$. This circumvents and tricks the will of the people and a waste their rights for the benefit of those who do not deserve.

\section{Section V: The participation of women in the judiciary}

Women starting joining the Judicial Institute in 1976 and many woman graduates have been appointed as judges and prosecutors. But in1984 and 2003 the former regime have prevented women from attending the judicial institute and thus limited the number of women judges who have been appointed before this decision and their number ranged of between 9-11 judges. Also were 25 women out of 235 students enrolled in the Iraqi Judicial Institute in $2006^{32}$. This shows that the representation of women in the judiciary is still minimal. In addition to that there are only 13 women judges out of 738 judges in Iraq (except the province of Kurdistan); 


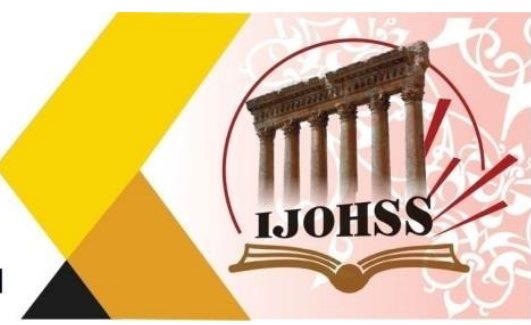

this is less than $2 \%$. While there are three female judges in the province of Kurdistan, particularly in Sulaymaniyah, who works as judges in juvenile courts ${ }^{33}$.

The representation of women in the public prosecution is better off; women occupy 16 of 250 positions in the middle and southern of Iraq. Also there are approximately 150 women working in the public prosecutor's office in the Kurdistan region. This shows the important fact that prosecutors do not have the ability to make decisions in issues even in the early stages of the investigation ${ }^{34}$.

\section{Section VI: The role of women in army and police}

In fact, many women in Iraq want to join the police and the military, but they face more obstacles. The most important of these obstacles is community's rejection of these ideas as well as the presence of other obstacles related to legislation and laws which have been enacted by Saddam Hussein's regime, which are still valid now. These laws prevent the Iraqi women to obtain the rank of police officer or the rank of army officer.

Many Iraqi women have been involved in the ranks of the Iraqi police and army because of the harsh living conditions unemployment and lack of job opportunities. In addition, there were no requirements or qualifications to join the ranks of the police and the army. Also women's nomination to the ministries of Defense and Interior are limited and few because the concentration of these ministries to reset officers of the previous Iraqi army ${ }^{35}$.

Coalition forces have worked since 2003 to recruit and train the Iraqi women to work in the Iraqi security forces. American commanders said the that Iraqi women soldiers can carry out inspection and intelligence gathering better information than male recruits as well as they own neutrality more than men regarding peacekeeping.

Hence, the coalition's efforts in 2003 have succeeded in recruiting two Iraqi women within the Baghdad police academy. After that five women have been recruited after taking permission from their tribal leaders to do it. By 2004, the numbers of Iraqi women who are working in the Iraqi army and police have expanded to up to 500 women, of whom 270 women have worked in the police force ${ }^{36}$.

In addition, some Iraqi parliamentary women left their political work to engage in battlefield. For instance, Omaima Al-jabara who was killed in her Tikrit city during fighting the so-called the Islamic state in Iraq and Levant is only one example.

\section{Conclusion and Recommendations}

In spite of the threats and risks which have reached occasionally to rape, murder and kidnapping but, Iraqi women have shown the real face of women worldwide suffering from a lot of catastrophes and wars before and after 2003.The Iraqi women have participated in all political decision-making positions such as the government institutions, the army, police and other sites that require the presence of women on a permanent basis. The most important challenge is the Arab social heritage which restricts women to seize the available opportunity to get the position of a sovereign post or as a decision-maker. Although the Iraqi Constitution guarantees the participation of women in the political process, such participation remains limited. On 


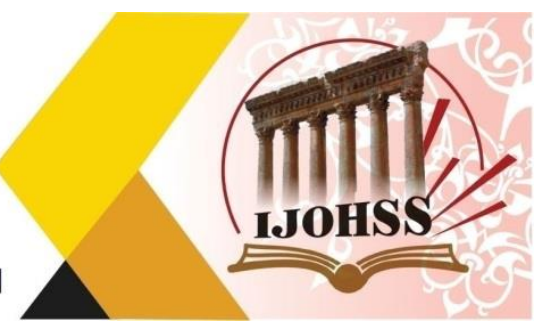

this basis, the role of Iraqi women in political participation is very limited and it is associated mainly with heads of blocs and not the member himself alike man or woman. Yet, research has recommended following recommendations:

1. Creating a motivational financial system of the political blocs by state to stimulate and bring feminist voice within the bloc. This step has been applied in many developing countries, including Mauritania, where it has achieved remarkable progress in the field of women's participation in parliament; the participation rate of women in the Mauritanian parliament reached 20\% until the end of 2006 after it was $8 \%$ in the previous years.

2. It is necessary to provide the right environment and safe haven of women by the heads of blocs and political parties and give them equal opportunities as men regarding express their opinions freely and the effective participation in important dialogues.

3. The adoption of mechanisms within the political parties and blocs based on the creation of the think tanks providing statistical studies and research concerning the of women's reality in the political field to motivate to the political involvement.

4. In case of the re-adoption a proportional representation law should be develop independent commission which does not tend to partisan sectarian trends and in order to achieve transparency. The committee function is the evaluation and study the names and backgrounds of candidates whether women or men who are nominated by the political blocs in the next elections. This study based on efficiency, integrity in the work for the benefit of the homeland, not for the political party.

5. Development of workshops by the state and the political blocs and parties in the field of women's political empowerment to enhance their cultural level and awareness.

6. Supporting civil society organizations to establish motivational political programs to educate and enhance the awareness of women, especially politically.

7. Formation of a feminist committee to survey the work of parliament's women to acknowledge mistakes which have been found to correct them.

8. Training and motivating the female college students to take part in the political participation and the other governmental programs. 


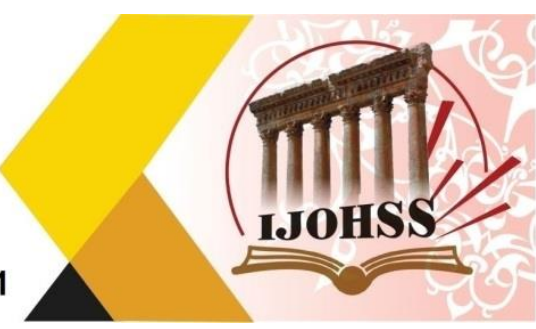

\section{Footnotes}

(1) Al-Ali, N. S. (2007). Iraqi women: Untold stories from 1948 to the present. Zed Books.

(2) Campbell, P., \& Howie, L. (2016). Fractured lives, digital selves: Writing the self in postinvasion Iraq. Journal of Sociology, 52(2), 235-248.

(3) Al-Ali, N. (2005). Reconstructing Gender: Iraqi women between dictatorship, war, sanctions and occupation. Third World Quarterly, 26(4-5), 739-758.

${ }^{(4)}$ Makiya, K. (1998). Republic of fear: The politics of modern Iraq. Univ of California Press.

${ }^{(5)}$ Saleh, Zainab. "Iraqi Women in Denmark: Ritual Performance and Belonging in Everyday Life by Marianne Holm Pedersen Manchester: Manchester University Press, 2014. 208 pp." American Anthropologist 118.3 (2016): 686-687.

(6) Al-Nouri, Q. N. (1993). Iraqi rural women's participation in domestic decision-making. Journal of Comparative Family Studies, 81-97.

(7) Moghadam, V. M. (2005). Peacebuilding and reconstruction with women: reflections on Afghanistan, Iraq and Palestine. Development, 48(3), 63-72.

${ }^{(8)}$ Al-Ali, N. S., \& Pratt, N. C. (2009). What kind of liberation?: women and the occupation of Iraq. Univ of California Press.

(9) Pratt, Nicola, and Nadje Al-Ali. "Positionalities, intersectionalities, and transnational feminism in researching women in post-invasion Iraq." Researching War. Routledge, 2016. 76-91.

${ }^{(10)}$ Brown, L., \& Romano, D. (2006). Women in Post-Saddam Iraq: One Step Foward or Two Steps Back?. NWSA Journal, 18(3), 51-70.

${ }^{(11)}$ Brown, L., \& Romano, D. (2006).

${ }^{(12)}$ Coleman, I. (2006). Women, Islam, and the new Iraq. Foreign affairs, 24-38.

${ }^{(13)}$ Coleman, I. (2006).

(14) CAMPBELL, P. (2015). DIGITAL SELVES: IRAQI WOMEN'S WARBLOGS AND THE LIMITS OF FREEDOM

${ }^{(15)}$ Deeks, A. S., \& Burton, M. D. (2007). Iraq's Constitution: A Drafting History. Cornell Int'l LJ,

${ }^{(16)}$ Krook, M. L., \& O'Brien, D. Z. (2010). The politics of group representation: Quotas for women and minorities worldwide. Comparative Politics, 253-272. 


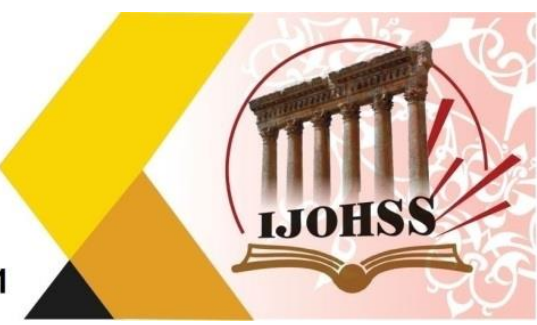

(17) Katzman, K. (2012, December). Iraq: Politics, Governance, and Human Rights. LIBRARY OF CONGRESS WASHINGTON DC CONGRESSIONAL RESEARCH SERVICE.

${ }^{(18)}$ CAMPBELL, P. (2015).

${ }^{(19)}$ Milbrath, L. W. (1965). Political participation: How and why do people get involved in politics?.

${ }^{(20)}$ Al-Ali, N. S., \& Pratt, N. C. (2006). Women in Iraq: Beyond the rhetoric. Middle East Reports, (239), 18-23.

(21) El-Kassem, N. (2008). The pitfalls of a 'democracy promotion'project for women of Iraq. International Journal of Lifelong Education, 27(2), 129-151.

${ }^{(22)}$ Elsadda, H. (2004). Women in the Arab World: reading against the Grain of Culturalism. Internationale Politik und Gesellschaft, 4(2004), 41-53.

${ }^{(23)}$ Zangana, H. (2008). Women and learning in the Iraqi war zone. International Journal of Lifelong Education, 27(2), 153-168.

(24) CAMPBELL, P. (2015)

${ }^{(25)}$ Dodge, Toby, et al. "Iraq synthesis paper: understanding the drivers of conflict in Iraq." (2018).

(26) Cerami, Alfio. "Complexity Theory, Democratic Transition and Public Policy Choices in Iraq." Democratic Transition and Public Policy Choices in Iraq (August 2, 2018) (2018).

(27) Judd, T. (2006). For the women of Iraq, the war is just beginning. The Independent, 8.

${ }^{(28)}$ Ferzan, K. K. (2004). Defending Imminence: From Battered Women to Iraq. Arizona Law Review, 46.

(29) Ibid.

(30) Al-Tamimi, Huda. "Effects of Iraq's Parliamentary Gender Quota on Women's Political Mobilization and Legitimacy Post-2003." Contemporary Arab Affairs 11.4 (2018): 41-62.

(31) Ibid.

${ }^{(32)}$ Chatterjee, Debangana. "Gendering ISIS and mapping the role of women." Contemporary Review of the Middle East 3.2 (2016).

${ }^{(33)}$ Voller, Y. (2014). Countering Violence against Women in Iraqi Kurdistan: State-Building and Transnational Advocacy. International Journal of Middle East Studies, 46(02), 351-372. 


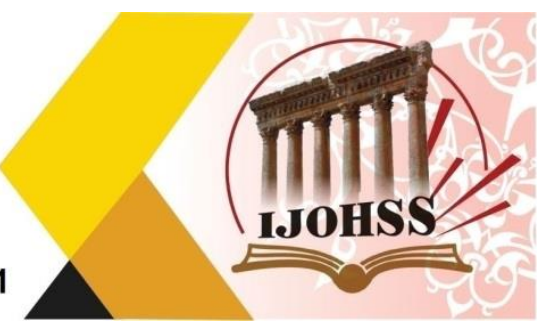

${ }^{(34)}$ Katzman, K. (2012)

${ }^{(35)}$ Krook, M. L., O'Brien, D. Z., \& Swip, K. M. (2010). Military Invasion and Women's Political Representation: Gender Quotas in Post-Conflict Afghanistan and Iraq.

(36) Khelghat-Doost, Hamoon. "Women of the Caliphate: The Mechanism for Women's incorporation into the Islamic State (IS)." Perspectives on terrorism 11.1 (2017).

\section{References}

1. Al-Ali, Nadje Sadig. Iraqi women: untold stories from 1948 to the present. Zed Books, 2007.

2. Al-Ali, Nadje. "Reconstructing Gender: Iraqi women between dictatorship, war, sanctions and occupation." Third World Quarterly 26.4-5 (2005): 739-758.

3. Al-Ali, N. S. (2007). Iraqi women: Untold stories from 1948 to the present. Zed Books.

4. Al-Ali, N. S., \& Pratt, N. C. (2006). Women in Iraq: Beyond the rhetoric. Middle East Reports, (239), 18-23.

5. Al-Ali, Nadje, and Nicola Pratt. What kind of liberation?: women and the occupation of Iraq. Univ of California Press, 2010.

6. Al-Tamimi, Huda. "Effects of Iraq's Parliamentary Gender Quota on Women's Political Mobilization and Legitimacy Post-2003." Contemporary Arab Affairs 11.4 (2018): 41-62.

7. Bhalotra, Sonia R., et al. Maternal Mortality and Women's Political Participation. No. 11590. Institute for the Study of Labor (IZA), 2018.

8. Campbell, Perri. Digital Selves: Iraqi Women's Warblogs and the Limits of Freedom. Illinois: Common Ground, 2015.

9. Campbell, Perri, and Luke Howie. "Fractured lives, digital selves: Writing the self in post-invasion Iraq." Journal of Sociology 52.2 (2016).

10. Cerami, Alfio. "Complexity Theory, Democratic Transition and Public Policy Choices in Iraq." Democratic Transition and Public Policy Choices in Iraq (August 2, 2018) (2018).

11. Coleman, I. (2006). Women, Islam, and the new Iraq. Foreign affairs.

12. El-Kassem, N. (2008). The pitfalls of a 'democracy promotion'project for women of Iraq. International Journal of Lifelong Education, 27(2).

13. Dodge, Toby, et al. "Iraq synthesis paper: understanding the drivers of conflict in Iraq." (2018).

14. Elsadda, H. (2004). Women in the Arab World: reading against the Grain of Culturalism. Internationale Politik und Gesellschaft, 4(2004).

15. CAMPBELL, P. (2015). DIGITAL SELVES: IRAQI WOMEN'S WARBLOGS AND THE LIMITS OF FREEDOM. 


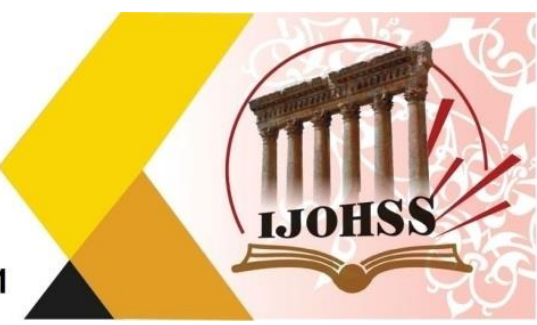

16. Chatterjee, Debangana. "Gendering ISIS and mapping the role of women." Contemporary Review of the Middle East 3.2 (2016).

17. Howie, Luke, and Perri Campbell. "Iraqi Women's Stories of Anxiety and Unrest from the Blogosphere." Crisis and Terror in the Age of Anxiety. Palgrave Macmillan, London, 2017.

18. Hatem, Mervat F. "Modernization, the state, and the family in Middle East women's studies." A social history of women and gender in the modern Middle East. Routledge, 2018.

19. Makiya, Kanan. Republic of fear: The politics of modern Iraq. Univ of California Press, 1998.

20. Krook, M. L., \& O'Brien, D. Z. (2010). The politics of group representation: Quotas for women and minorities worldwide. Comparative Politics.

21. Khelghat-Doost, Hamoon. "Women of the Caliphate: The Mechanism for Women's incorporation into the Islamic State (IS)." Perspectives on terrorism 11.1 (2017).

22. Kelly, Peter, et al. "Young People and the Politics of Outrage and Hope: An Introduction." Young People and the Politics of Outrage and Hope. BRILL, 2018.

23. Krook, M. L., O'Brien, D. Z., \& Swip, K. M. (2010). Military Invasion and Women's Political Representation: Gender Quotas in Post-Conflict Afghanistan and Iraq.

24. Saleh, Zainab. "Iraqi Women in Denmark: Ritual Performance and Belonging in Everyday Life by Marianne Holm Pedersen Manchester: Manchester University Press, 2014. 208 pp." American Anthropologist 118.3 (2016).

25. Milbrath, L. W. (1965). Political participation: How and why do people get involved in politics?.

26. Zangana, H. (2008). Women and learning in the Iraqi war zone. International Journal of Lifelong Education, 27(2), 153-168.

27. Wood, Reed M., and Jakana L. Thomas. "Women on the frontline: Rebel group ideology and women's participation in violent rebellion." Journal of Peace Research 54.1 (2017). 